\title{
Quantitative Estimation of the Changes in Soil CEC after the Removal of Organic Matter and Iron Oxides
}

\author{
Xiangzheng Kong1,2, Decheng $\mathrm{Li}^{1 *}$, Xiaodong Song1, Ganlin Zhang ${ }^{1}$ \\ ${ }^{1}$ State Key Laboratory of Soil and Sustainable Agriculture, Institute of Soil Science, Chinese Academy of Sciences, Nanjing, China \\ ${ }^{2}$ University of Chinese Academy of Sciences, Beijing, China \\ Email: kongxiangzhen@issas.ac.cn, *dcli@issas.ac.cn
}

How to cite this paper: Kong, X.Z., Li, D.C., Song, X.D. and Zhang, G.L. (2021) Quantitative Estimation of the Changes in Soil CEC after the Removal of Organic Matter and Iron Oxides. Agricultural Sciences, 12, 1244-1254.

https://doi.org/10.4236/as.2021.1211079

Received: October 8, 2021

Accepted: November 9, 2021

Published: November 12, 2021

Copyright $\odot 2021$ by author(s) and Scientific Research Publishing Inc. This work is licensed under the Creative Commons Attribution-NonCommercial International License (CC BY-NC 4.0). http://creativecommons.org/licenses/by-nc/4.0/ (c) (i) (8) Open Access

\begin{abstract}
The removal of organic matter and iron oxides could increase and decrease soil CEC in tropical and subtropical regions, but the quantitative information is insufficient so far about the change of soil CEC, the influence factors and their contribution. In this study, the subhorizon soils of 24 soil series in the tropical and subtropical China were used, $\mathrm{pH}$, particle size composition, organic matter, iron oxides of these samples were measured, and also CECs were measured and compared for the original soils and after the removal of organic matter and iron oxides. The results showed that, compared with CEC of the original soil, the eliminating organic matter increased soil CEC significantly by $2.28 \%-56.50 \%$ with a mean of $24.02 \%$, but the further obliterating iron oxides decreased soil CEC significantly by $0.75 \%-20.30 \%$ with a mean of $7.73 \%$. CEC after the removal of organic matter and iron oxides had positive correlation with iron oxides $(\mathrm{p}<0.01)$ and negative correlation with sand content $(\mathrm{p}<0.01$ and $\mathrm{p}<0.05)$. CEC after organic matter eliminated was mainly decided by iron oxides $(51.68 \%)$, followed by silt content (22.19\%); while CEC after iron oxides obliterated was mainly determined by iron oxides $(50.55 \%)$. The increase of CEC after organic matter eliminated was co-affected by the contents of clays, slits, iron oxides and $\mathrm{pH}(22.00 \%$ 27.34\%), while the decrease of CEC after iron oxides obliterated further was dominated by the content of organic matter (66.92\%). More other soil parameters should be considered for higher predicting accuracy in the regression model of soil CEC after the removal of organic matter and iron oxides, and the recommended optimal models obtained in this study were as follows: for soil CEC after organic matter eliminated, CEC $=1.665-0.546 \mathrm{pH}-0.024 \mathrm{OM}$ $+0.053 \mathrm{Fe}_{\mathrm{x}} \mathrm{O}_{\mathrm{y}}-0.001 \mathrm{Silt}+0.007$ Clay $+0.972 \mathrm{CEC}_{\text {original }}\left(\mathrm{R}^{2}\right.$ was 0.923 , RSME was $\left.1.55 \mathrm{cmol}(+) \cdot \mathrm{kg}^{-1}, \mathrm{p}<0.01\right)$, while for soil CEC after iron oxides further
\end{abstract}


obliterated, $\mathrm{CEC}=1.665-0.546 \mathrm{pH}-0.024 \mathrm{OM}+0.053 \mathrm{Fe}_{\mathrm{x}} \mathrm{O}_{\mathrm{y}}-0.001 \mathrm{Silt}+$ 0.007 Clay $+0.972 \mathrm{CEC}_{\text {original }}\left(\mathrm{R}^{2}\right.$ was 0.923 , RMSE was $1.55 \mathrm{cmol}(+) \cdot \mathrm{kg}^{-1}, \mathrm{p}<$ $0.01)$. Further research is needed in the future as for exploring internal functional mechanism in view of soil electrochemistry and mineralogy.

\section{Keywords}

Soil CEC, Quantitative Estimation, Removal, Organic Matter, Iron Oxides

\section{Introduction}

It was found early that CEC of the soils in tropical and subtropical regions would be increased after the removal of organic matter, and then decreased after the further removal of iron oxides [1] [2], the former could be attributed to the adsorption of organic matter by clays [3] [4] [5] [6], which hinders the adsorption of charges, and the latter could be attributed to the characteristics that iron oxides also are partial clays and may dominate soil CEC [7] [8]. However, so far litter is known about the change degree of soil CEC after the removal of organic matter and iron oxides, and the influence factors and their contribution. Thus, a brief study was conducted with the typical subhorizon soils from soil series in tropical and subtropical China in order to: 1) disclose the change degree of soil CEC after the removal of organic matter and iron oxides, 2) clarify the influence factors and their contribution to the change degree of soil CEC, 3) establish the predicting model of soil CEC from other parameters after the removal of organic matter and iron oxides.

\section{Materials and Methods}

\subsection{Background of Tested Soil Samples}

Figure 1 shows the spatial distribution of 24 soil series used in this study in tropical and subtropical China [9]-[15]. The removal of organic matter and iron oxide were based on the extraction method of soil clays [16] [17], which were mainly as follows: 1) firstly, $0.2 \mathrm{~mol} \cdot \mathrm{L}^{-1}$ and $0.05 \mathrm{~mol} \cdot \mathrm{L}^{-1} \mathrm{HCl}$ were used respectively to decompose calcium carbonate and wash away $\mathrm{Ca}^{2+}$ from soil samples sieved through $2 \mathrm{~mm}$ nylon mesh; 2) secondly, 1:4 $\mathrm{H}_{2} \mathrm{O}_{2}$ was dropped to the soil samples until no bubbles $\left(\mathrm{CO}_{2}\right)$ are presented and the soil color becomes light, indicating organic matter is fully removed; 3) finally, sodium citrate-sodium bicarbonate-sodium disulfite (DCB) was used to dissolve iron oxides in soil samples, and then TG20G high-speed centrifuge was used to fully eliminate away the dissolved iron oxides.

For the determination of soil parameters, the pipette method was used to measure the particle size distribution, the potentiometer method (soil:water = 1:2.5) was used to determine $\mathrm{pH}$ value, the Walkley-Black wet oxidation method was used to decide the content of organic matter, the phenanthroline colorimetry 


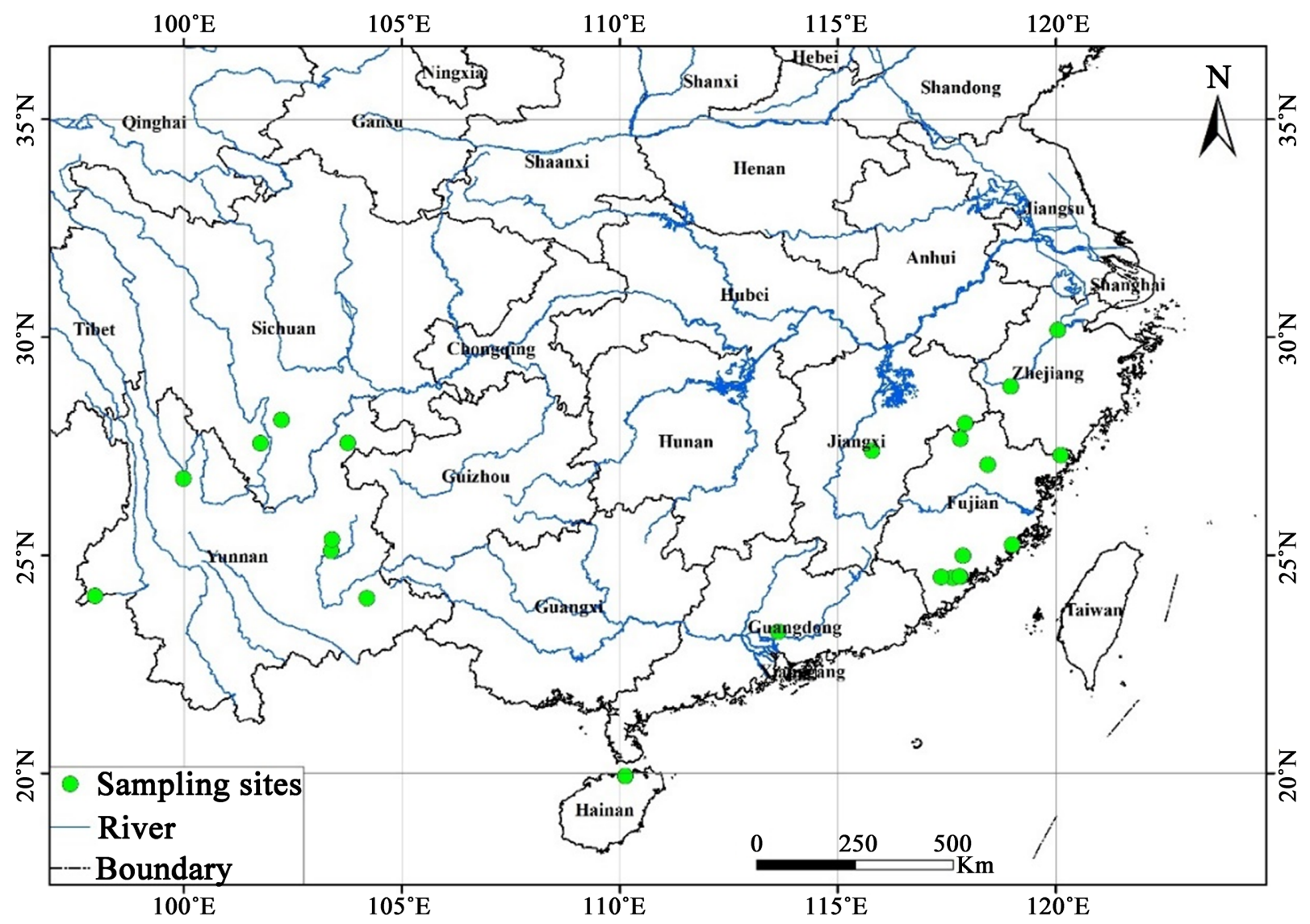

Figure 1. Spatial distribution of 24 soil series used in this study in tropical and subtropical China.

method was used to obtain the content of iron oxides, the $\mathrm{NH}_{4} \mathrm{OAc}(\mathrm{pH}$ 7.0) exchange method was used to measure the CEC values of original soil sample $\left(\mathrm{CEC}_{1}\right)$ and after the removal of organic matter $\left(\mathrm{CEC}_{2}\right)$ and iron oxides $\left(\mathrm{CEC}_{3}\right)$ [16] [17].

\subsection{Data Statistical Analysis}

Microsoft Excel 2016 and IBM Statistics SPSS 22.0 software were used for statistical analysis of the data, and Duncan test method (2-tailed) were used for variance analyses and multiple comparisons.

\section{Results}

\subsection{Statistical Results of Soil Parameters}

Table 1 lists the measured values of soil parameters, it showed that soil CEC was $5.12-19.90 \mathrm{cmol}(+) \cdot \mathrm{kg}^{-1}$ with a mean of $11.16 \mathrm{cmol}(+) \cdot \mathrm{kg}^{-1}$, after organic matter eliminated, soil CEC significantly increased to $7.36-25.71 \mathrm{cmol}(+) \cdot \mathrm{kg}^{-1}$ with a mean of $13.64 \mathrm{cmol}(+) \cdot \mathrm{kg}^{-1}(\mathrm{p}<0.01)$, increased by $2.28 \% \sim 56.50 \%$ with a mean of $24.02 \%$; but after further iron oxides was obliterated, soil CEC then decreased to 6.97 to $23.68 \mathrm{cmol}(+) \cdot \mathrm{kg}^{-1}$ with a mean of $12.59 \mathrm{cmol}(+) \cdot \mathrm{kg}^{-1}(\mathrm{p}<0.01)$, decreased by $0.75 \%-20.30 \%$ with a mean of $7.73 \%$. 


\subsection{Parameters Influencing Soil CEC}

Table 2 lists Pearson correlation between soil CEC with other parameters, it could be found that $\mathrm{CEC}_{1}$ had positive correlation with iron oxides $(\mathrm{p}<0.01)$ and silt content $(\mathrm{p}<0.05)$ but negative correlation with sand content $(\mathrm{p}<0.05)$. $\mathrm{CEC}_{2}$ and $\mathrm{CEC}_{3}$ had positive correlation with iron oxides $(\mathrm{p}<0.01)$ but negative correlation with sand content $(\mathrm{p}<0.01$ and $\mathrm{p}<0.05)$, while $\Delta \mathrm{CEC}_{3-2}$ had negative

Table 1. Statical descriptions of soil parameters $(n=24)$.

\begin{tabular}{ccccccc}
\hline Soil parameter & Min. & Max. & Mean \pm S.D. & C.V.(\%) & Skewness & Kurtosis \\
\hline CEC $_{1}$ & 5.12 & 19.90 & $11.16 \pm 4.06$ & 36.36 & 0.64 & -0.75 \\
$\mathrm{CEC}_{2}$ & 7.39 & 25.71 & $13.64 \pm 4.80$ & 35.16 & 0.87 & 0.13 \\
$\mathrm{CEC}_{3}$ & 6.97 & 23.68 & $12.59 \pm 4.58$ & 36.33 & 1.01 & 0.13 \\
$\Delta \mathrm{CEC}_{2-1}$ & 2.28 & 56.50 & $24.02 \pm 16.62$ & 69.21 & 0.48 & -0.78 \\
$\left.\Delta \mathrm{CEC}_{3-2}\right)$ & -0.75 & -20.30 & $-7.73 \pm-4.55$ & -58.89 & -0.94 & 1.40 \\
pH & 4.39 & 6.68 & $5.17 \pm 0.62$ & 12.07 & 0.96 & 0.46 \\
Organic matter & 3.10 & 33.57 & $10.90 \pm 8.17$ & 74.93 & 1.39 & 1.21 \\
Iron oxides & 19.25 & 80.84 & $41.65 \pm 16.31$ & 39.15 & 0.71 & -0.20 \\
Sand & 70 & 640 & $302 \pm 168$ & 55.66 & 0.59 & -0.80 \\
Silt & 116 & 517 & $331 \pm 117$ & 35.18 & -0.37 & -0.82 \\
Clay & 173 & 596 & $366 \pm 107$ & 29.27 & 0.03 & -0.09 \\
\hline
\end{tabular}

Note: 1) CEC, cmol (+). $\mathrm{kg}^{-1}$; sand, silt, clay, organic matter and iron oxides, $\mathrm{g}^{\mathrm{kg}} \mathrm{kg}^{-1}$; 2) $\mathrm{CEC}_{1}$, original soil CEC; CEC 2 , soil CEC after organic matter eliminated; $\mathrm{CEC}_{3}$, soil CEC after organic matter and iron oxides obliterated; $\triangle \mathrm{CEC}_{2-1}=\left(\mathrm{CEC}_{2}-\mathrm{CEC}_{1}\right) \times$ $100 / \mathrm{CEC}_{1} ; \quad \Delta \mathrm{CEC}_{3-2}=\left(\mathrm{CEC}_{3}-\mathrm{CEC}_{2}\right) \times 100 / \mathrm{CEC}_{2}$, The Same Below; 3$)$ data of CEC followed by different capitals are significantly different at $\mathrm{p}<0.01$ level.

Table 2. Pearson correlation between soil CEC and other parameters.

\begin{tabular}{|c|c|c|c|c|c|c|c|}
\hline CEC & Correlation & $\mathrm{pH}$ & Organic matter & Iron oxides & Sand & Silt & Clay \\
\hline \multirow[t]{2}{*}{$\mathrm{CEC}_{1}$} & Pearson Correlation & 0.116 & 0.117 & $0.574^{\star \star}$ & $-0.446^{\star}$ & $0.465^{*}$ & 0.193 \\
\hline & Sig. (2-tailed) & 0.588 & 0.586 & 0.003 & 0.029 & 0.022 & 0.366 \\
\hline \multirow[t]{2}{*}{$\mathrm{CEC}_{2}$} & Pearson Correlation & 0.030 & 0.071 & $0.679^{\star *}$ & $-0.518^{\star *}$ & 0.399 & 0.379 \\
\hline & Sig. (2-tailed) & 0.888 & 0.743 & 0.000 & 0.010 & 0.054 & 0.068 \\
\hline \multirow[t]{2}{*}{$\mathrm{CEC}_{3}$} & Pearson Correlation & 0.059 & -0.009 & $0.662^{\star \star}$ & $-0.508^{*}$ & 0.362 & 0.403 \\
\hline & Sig. (2-tailed) & 0.784 & 0.965 & 0.000 & 0.011 & 0.082 & 0.051 \\
\hline \multirow[t]{2}{*}{$\triangle \mathrm{CEC}_{2-1}$} & Pearson Correlation & -0.243 & -0.022 & 0.241 & -0.072 & -0.177 & 0.306 \\
\hline & Sig. (2-tailed) & 0.253 & 0.920 & 0.256 & 0.737 & 0.409 & 0.147 \\
\hline \multirow[t]{2}{*}{$\triangle \mathrm{CEC}_{3-2}$} & Pearson Correlation & 0.196 & $-0.548^{\star \star}$ & -0.136 & 0.057 & -0.201 & 0.129 \\
\hline & Sig. (2-tailed) & 0.359 & 0.006 & 0.526 & 0.790 & 0.346 & 0.548 \\
\hline
\end{tabular}

Note: $1{ }^{\star} .{ }^{\star *}$, Correlation is significant at $\mathrm{p}<0.05$ or 0.01 level (2-tailed). 
correlation with organic matter $(\mathrm{p}<0.01)$.

The contribution of one parameter to CEC was calculated as the follows: firstly, all parameters were normalized by the Z-score method with IBM Statistics SPSS software to ensure them with the same magnitude, and then the regression coefficients between each parameter with CEC was used to indicate their contribution to CEC [18] [19] [20]. The contribution of one parameter $\left(C_{i}\right)$ to CEC was calculated as $C_{i}=/ K_{i} / / / K_{\text {sum }} /$, in which $K_{i}$ is the regression coefficient of the $i$ parameter, and $K_{\text {sum }}$ is the total sum of all coefficients. The obtained linear regression models of CEC with other parameters were listed in Table 3, and the calculated contribution of other parameters to CEC were listed in Table 4.

In view of the contribution of other parameters to CEC, it could be roughly seen from Table 4 that $\mathrm{CEC}_{1}$ and $\mathrm{CEC}_{2}$ was mainly decided by the content of iron oxides $(47.17 \%$ and $51.68 \%)$, followed by the content of silts $(31.39 \%$ and $22.19 \%) ; \mathrm{CEC}_{3}$ was mainly determined by the content of iron oxides $(50.55 \%)$; $\triangle \mathrm{CEC}_{2-1}$ was mainly affected by the contents of clays $(27.34 \%)$, slits $(25.82 \%)$, iron oxides $(24.73 \%)$ and $\mathrm{pH}(22.00 \%) ; \Delta \mathrm{CEC}_{3-2}$ was mainly influenced by the content of organic matter (66.92\%).

\subsection{Correlation between Soil CEC}

Table 5 lists Pearson correlation between various soil CEC, positive correlation was found between $\mathrm{CEC}_{1}, \mathrm{CEC}_{2}$ and $\mathrm{CEC}_{3}\left(\mathrm{R}^{2}\right.$ was 0.918 - 0.989 with Sig. = 0.000 ), but no correlation was found between $\triangle \mathrm{CEC}_{2-1}$ and $\triangle \mathrm{CEC}_{3-2}$ with $\mathrm{CEC}_{1}$, $\mathrm{CEC}_{2}$ and $\mathrm{CEC}_{3}$.

Table 3. Linear regression model between normalized CEC and other soil properties.

\begin{tabular}{lcccc}
\hline \multicolumn{1}{c}{ Liner regression model } & $\mathbf{R}^{2}$ & RMSE & F & Sig. \\
\hline $\mathrm{CEC}_{1}=2.031 \times 10^{-16}-0.004 \mathrm{pH}-0.157 \mathrm{OM}+0.550 \mathrm{Fe}_{\mathrm{x}} \mathrm{O}_{\mathrm{y}}+0.366 \mathrm{Silt}-0.089$ Clay & 0.450 & 0.84 & 2.91 & $0.041^{*}$ \\
$\mathrm{CEC}_{2}=-2.354 \times 10^{-16}-0.074 \mathrm{pH}-0.170 \mathrm{OM}+0.631 \mathrm{Fe}_{\mathrm{x}} \mathrm{O}_{\mathrm{y}}+0.271$ Silt $+0.075 \mathrm{Clay}$ & 0.550 & 0.75 & 4.41 & $0.009^{* *}$ \\
$\mathrm{CEC}_{3}=-6.433 \times 10^{-16}-0.060 \mathrm{pH}-0.243 \mathrm{OM}+0.640 \mathrm{Fe}_{\mathrm{x}} \mathrm{O}_{\mathrm{y}}+0.247 \mathrm{Silt}+0.076 \mathrm{Clay}$ & 0.543 & 0.76 & 4.28 & $0.010^{*}$ \\
$\Delta \mathrm{CEC}_{2-1}=-6.472 \times 10^{-16}-0.202 \mathrm{pH}-0.001 \mathrm{OM}+0.227 \mathrm{Fe}_{\mathrm{x}} \mathrm{O}_{\mathrm{y}}-0.237$ Silt $+0.251 \mathrm{Clay}$ & 0.223 & 0.10 & 1.03 & 0.429 \\
$\Delta \mathrm{CEC}_{3-2}=-4.376 \times 10^{-16}+0.078 \mathrm{pH}-0.532 \mathrm{OM}+0.052 \mathrm{Fe}_{\mathrm{x}} \mathrm{O}_{\mathrm{y}}-0.095$ Silt $-0.038 \mathrm{Clay}$ & 0.314 & 0.94 & 1.65 & 0.199 \\
\hline
\end{tabular}

Note: $\mathrm{OM}$, organic matter; $\mathrm{Fe}_{\mathrm{x}} \mathrm{O}_{\mathrm{y}}$, iron oxides.

Table 4. Contribution of other soil properties to CEC (\%).

\begin{tabular}{cccccccc}
\hline Property & $\mathrm{pH}$ & Organic matter & Iron oxides & Sand & Silt & Clay & Total \\
\hline $\mathrm{CEC}_{1}$ & 0.34 & 13.46 & 47.17 & 0 & 31.39 & 7.63 & 100 \\
$\mathrm{CEC}_{2}$ & 6.06 & 13.92 & 51.68 & 0 & 22.19 & 6.14 & 100 \\
$\mathrm{CEC}_{3}$ & 4.74 & 19.19 & 50.55 & 0 & 19.51 & 6.00 & 100 \\
$\Delta \mathrm{CEC}_{2-1}$ & 22.00 & 0.11 & 24.73 & 0 & 25.82 & 27.34 & 100 \\
$\Delta \mathrm{CEC}_{3-2}$ & 9.81 & 66.92 & 6.54 & 0 & 11.95 & 4.78 & 100 \\
\hline
\end{tabular}


Table 5. Pearson correlation between soil CEC.

\begin{tabular}{cccccc}
\hline CEC & Correlation & CEC $_{2}$ & CEC $_{3}$ & $\Delta$ CEC $_{2-1}$ & $\Delta$ CEC $_{3-2}$ \\
\hline CEC $_{1}$ & Pearson Correlation & $0.927^{* *}$ & $0.918^{* *}$ & -0.311 & 0.057 \\
& Sig. (2-tailed) & 0.000 & 0.000 & 0.139 & 0.790 \\
$\mathrm{CEC}_{2}$ & Pearson Correlation & & $0.989^{* *}$ & 0.051 & 0.033 \\
& Sig. (2-tailed) & & 0.000 & 0.812 & 0.878 \\
$\mathrm{CEC}_{3}$ & Pearson Correlation & & & 0.036 & 0.177 \\
& Sig. (2-tailed) & & 0.867 & 0.407 \\
$\mathrm{CEC}_{2-1}$ & Pearson Correlation & & & -0.130 \\
& Sig. (2-tailed) & & & 0.544 \\
\hline
\end{tabular}

Note: ${ }^{\star} .{ }^{\star \star}$, Correlation is significant at $\mathrm{p}<0.05$ or 0.01 level (2-tailed).

Table 6. Predicting models of clay $\mathrm{CEC}_{7}$.

\begin{tabular}{|c|c|c|c|c|c|}
\hline & Predicting model & $\mathbf{R}^{2}$ & RMSE & $\mathbf{F}$ & Sig. \\
\hline 1 & $\mathrm{CEC}_{1}=3.453-0.024 \mathrm{pH}-0.078 \mathrm{OM}+0.137 \mathrm{Fe}_{2} \mathrm{O}_{3}+0.013$ Silt -0.003 Clay & 0.450 & 3.60 & 2.94 & 0.041 \\
\hline 2 & $\mathrm{CEC}_{2}=5.022-0.569 \mathrm{pH}-0.100 \mathrm{OM}+0.185 \mathrm{Fe}_{2} \mathrm{O}_{3}+0.011$ Silt +0.003 Clay & 0.550 & 3.64 & 4.41 & 0.009 \\
\hline 3 & $\mathrm{CEC}_{2}=1.418+1.095 \mathrm{CEC}_{1}$ & 0.859 & 1.84 & 133.70 & 0.000 \\
\hline 4 & $\mathrm{CEC}_{2}=1.665-0.546 \mathrm{pH}-0.024 \mathrm{OM}+0.053 \mathrm{Fe}_{2} \mathrm{O}_{3}-0.001 \mathrm{Silt}+0.007$ Clay $+0.972 \mathrm{CEC}_{1}$ & 0.923 & 1.55 & 33.81 & 0.000 \\
\hline 5 & $\mathrm{CEC}_{3}=4.452-0.438 \mathrm{pH}-0.136 \mathrm{OM}+0.180 \mathrm{Fe}_{2} \mathrm{O}_{3}+0.010$ Silt +0.003 Clay & 0.543 & 3.49 & 4.27 & 0.010 \\
\hline 6 & $\mathrm{CEC}_{3}=1.038+1.035 \mathrm{CEC}_{1}$ & 0.843 & 1.85 & 118.46 & 0.000 \\
\hline 7 & $\mathrm{CEC}_{3}=1.222-0.415 \mathrm{pH}-0.063 \mathrm{OM}+0.052 \mathrm{Fe}_{2} \mathrm{O}_{3}-0.002 \mathrm{Silt}+0.006 \mathrm{Clay}+0.935 \mathrm{CEC}_{1}$ & 0.922 & 1.49 & 33.34 & 0.000 \\
\hline
\end{tabular}

\subsection{Predicting $\mathrm{CEC}_{2}$ and $\mathrm{CEC}_{3}$ Based on Other Parameters and $\mathrm{CEC}_{1}$}

By using IBM Statistics SPSS, the regression models of $\mathrm{CEC}_{2}, \mathrm{CEC}_{3}, \triangle \mathrm{CEC}_{2-1}$ and $\triangle \mathrm{CEC}_{3-2}$ with other parameters and $\mathrm{CEC}_{1}$ were obtained (see Table 6), and it could be found by comparison from Table 6 that Model 3 and Model 4 could be recommended were suitable for the prediction of $\mathrm{CEC}_{2}$ while Model 6 and Model 7 for the prediction of $\mathrm{CEC}_{3}$, respectively, in which Model 4 and Model 6 were optimal for $\mathrm{CEC}_{2}$ and $\mathrm{CEC}_{3}$ prediction, respectively.

\section{Discussions}

Our study showed (see Table 1) that, for the subhorizon soils in tropical and subtropical China, clay and silt contents were meanly $331 \mathrm{~g} \cdot \mathrm{kg}^{-1}$ and $302 \mathrm{~g} \cdot \mathrm{kg}^{-1}$

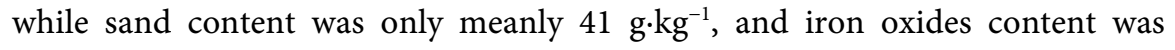
meanly $41.65 \mathrm{~g} \mathrm{~kg}^{-1}$, which prove further that soils in tropical and subtropical China are clayey and rich in iron oxides [21].

It was found early that CEC of the soils in tropical and subtropical regions would be increased after the removal of organic matter, and then decreased after 
the further removal of iron oxides [1] [2]. For the subhorizon soils in tropical and subtropical China, compared with previous studies, our study further quantitatively disclosed the change of soil CEC after the removal of organic matter and iron oxides. The results showed that soil CEC could be significantly increased by $2.28 \%-56.50 \%$ with a mean of $24.02 \%$ ( $p<0.01$ ) after the elimination of organic matter, and then it could be significantly decreased by $0.75 \%$ $20.30 \%$ with a mean of $7.73 \%$ after further obliteration of iron oxides $(\mathrm{p}<0.01)$. Our study also found that the increased degree of soil CEC after organic matter had no correlation with other parameters $(\mathrm{pH}$, the contents of organic matter, iron oxides and particle size composition ( $\mathrm{R}$ was $0.022-0.306$, Sig. was 0.147 0.920 ); while the decreased degree of soil CEC after iron oxides was obliterated only had negative correlation with the content of organic matter ( $\mathrm{R}$ was $0.548^{* *}$, Sig. was 0.1006). In view of the contribution of other parameters to CEC, our study roughly showed that both soil original CEC and CEC after the removal of organic matter were mainly decided by iron oxides (47.17\% and $51.68 \%)$, followed by the content of silt content (31.39\% and $22.19 \%)$, but CEC after further obliteration of iron oxides was mainly determined by iron oxides $(50.55 \%)$; while the increase caused by the removal of organic matter was co-affected by the contents of $\mathrm{pH}$, silts, clays and iron oxides $(22.00 \%-27.34 \%)$, and the decrease resulted from further obliteration of iron oxides was dominantly influenced by OM content (66.92\%).

Previous studies showed that $\mathrm{pH}$ usually has positive correlation with soil CEC for acid soils [22] [23] [24] [25] [26], however, no significant positive correlation was found in our study between $\mathrm{pH}$ and soil CEC ( $\mathrm{R}$ was $0.116, \mathrm{p}=$ 0.588 ), which could be attributed to narrow range of $\mathrm{pH}$ of the soil samples used in our study (acid, 4.39 - 6.68 with a mean of $5.17 \mathrm{in} \mathrm{pH}$ ). Organic matter usually has significant positive correlation with soil CEC [22] [24]-[34], but our results neither found that organic matter had significant correlation with soil CEC ( $R$ was $0.117, p=0.586$ ), which could also be related to the content of organic matter [27] [33] [34] [35] in subhorizon soils used in our study (meanly 10.90 $\left.\mathrm{g} \cdot \mathrm{kg}^{-1}\right)$. Clay content usually also has significant positive correlation with soil CEC [22] [23] [24] [25] [26] [28]-[34] [36], but our results neither found such a phenomenon ( $\mathrm{R}$ was $0.193, \mathrm{p}=0.366$ ), which possibly could be attributed to high content of clay contents in our soil samples (meanly $366 \mathrm{~g} \cdot \mathrm{kg}^{-1}$ ). Our study found that iron oxides was significantly positively correlated with soil CEC ( $R$ was $0.574, \mathrm{p}<0.01$ ), few studies analyzed the correlation between iron oxides and soil CEC because iron oxides in subtropical and tropical soils usually exist as clay fraction or strongly cemented with clays [21] [36] [37] [38]. Significant negative correlation was found between soil CEC with sand content in our study, which is consist with the previous studies [22] [31] [33] [34] [35], and could be attributed to sand fraction mainly composed of quartz and iron concretions with low charge density [39]. Moreover, significant positive correlation was also found between soil CEC with silt content in our study as in other studies [23] 
[25], which could be attributed to that silt fraction is often composed of vermiculite and mica minerals which can hold negative charges [39] [40].

Removing organic matter and iron oxides from soils and measuring soil CEC are tedious and troublesome processes, so it is helpful to find the predicting model for soil CEC changes after the removal of organic matter and iron oxides if necessary. In our study, various regression models were established, and it was found that model with more parameters usually was higher in accuracy. By comparation, two optimal models are recommended as the optimal predicting model for soil CEC after the removal of organic matter and iron oxides respectively (see Table 6, Model 4 and Model 7, with $\mathrm{R}^{2}$ of 0.923 and 0.922, RMSE of $1.55 \mathrm{cmol}(+) \cdot \mathrm{kg}^{-1}$ and $1.49 \mathrm{cmol}(+) \cdot \mathrm{kg}^{-1}$, and $\left.\mathrm{p}<0.01\right)$.

It should be pointed out that our study only focused on quantitative estimating the change degrees of soil CEC after the removal of organic matter and iron oxides and the influence factors and their contribution to the changes, however, further research is needed in the future as for exploring internal functional mechanism in view of soil electrochemistry and mineralogy.

\section{Conclusion}

Our study quantitatively disclosed the significant increase and decrease of soil CEC after the removal of organic matter and iron oxides in tropical and subtropical China, and found that the increase degree of soil CEC after the elimination of organic matter was co-affected by the contents of clays, slits, iron oxides and $\mathrm{pH}$, while the decrease degree of soil CEC after the further obliteration of iron oxides was dominated by OM content. More other parameters should be considered for higher accuracy in predicting soil CEC after the removal of organic matter and iron oxides.

\section{Acknowledgements}

This study was supported by projects of the National Natural Science Foundation of China (No. 41877008) and the National S \& T Basic Special Foundation Project (No. 2014FY110200). We would like to express thanks to the contribution of all colleagues in the data preparation and the establishment of the soil series.

\section{Conflicts of Interest}

The authors declare no conflicts of interest regarding the publication of this paper.

\section{References}

[1] Mattson, S. (1931) The Laws of Soil Colloidal Behavior: VI. Amphoteric Behavior. Soil Science, 32,343-366. https://doi.org/10.1097/00010694-193111000-00002

[2] Yu, T.R. (1981) Variable Charge Soil. Chinese Journal of Soil Science, No. 5, 40-45.

[3] Chassé, A.W. and Ohno, T. (2016) Higher Molecular Mass Organic Matter Molecules Compete with Orthophosphate for Adsorption to Iron (Oxy)hydroxide. Envi- 
ronmental Science \& Technology, 50, 7641-7649.

https://doi.org/10.1021/acs.est.6b01582

[4] Saidy, A.R., Smernik, R.J., Baldock, J. A., et al. (2013) The Sorption of Organic Carbon onto Differing Clay Minerals in the Presence and Absence of Hydrous Iron Oxide. Geoderma, 209, 15-21. https://doi.org/10.1016/j.geoderma.2013.05.026

[5] Oren, A. and Chefetz, B. (2012) Sorptive and Desorptive Fractionation of Dissolved Organic Matter by Mineral Soil Matrices. Journal of Environmental Quality, 41, 526-533. https://doi.org/10.2134/jeq2011.0362

[6] Mayes, M.A., Heal, K.R., Brandt, C.C., et al. (2012) Relation between Soil Order and Sorption of Dissolved Organic Carbon in Temperate Subsoils. Soil Science Society of America Journal, 76, 1027-1037. https://doi.org/10.2136/sssaj2011.0340

[7] Huang, C.Y. (2000) Pedology. China Agriculture Press, Beijing.

[8] Zhang, Z.Y. (2016) Composition and Evaluation Characteristics of Clay Minerals in Several Horizontal Zonality Soil Particles. Huazhong Agricultural University, Wuhan.

[9] Wang, T.W. and Chen, J.Y. (2020) Soil Series of China (Jiangxi Volume). Science Press, Beijing.

[10] Huang, B. and Lu, S.G. (2020) Soil Series of China (Yunnan Volume). Science Press, Beijing.

[11] Yuan, D.G. (2020) Soil Series of China (Sichuan Volume). Science Press, Beijing.

[12] Zhang, M.K. and Ma, W.C. (2017) Soil Series of China (Fujian Volume). Science Press, Beijing.

[13] Lu, Y. (2017) Soil Series of China (Guangdong Volume). Science Press, Beijing.

[14] Ma, W.C. and Zhang, M.K. (2017) Soil Series of China (Zhejiang Volume). Science Press, Beijing.

[15] Qi, Z.P., Wang, D.F. and Wei, Z.Y. (2018) Soil Series of China (Hainan Volume). Science Press, Beijing.

[16] Zhang, G.L. and Gong, Z.T. (2012) Soil Survey Laboratory Methods. Science Press, Beijing.

[17] Bao, S.D. (2000) Analysis for Soil and Agro-Chemistry. 3rd Edition, China Agriculture Press, Beijing.

[18] Krogh, L.H., Breuning, M. and Greve, H.M. (2000) Cation-Exchange Capacity Pedotransfer Functions for Danish Soils. Acta Agriculturae Scandinavica Section B-Soil and Plant Science, 50, 1-12. https://doi.org/10.1080/090647100750014358

[19] Meghdadi, A. and Javar, N. (2018) Evaluation of Nitrate Sources and the Percent Contribution of Bacterial Denitrification in Hyporheic Zone Using Isotope Fractionation Technique and Multi-Linear Regression Analysis. Journal of Environmental Management, 222, 54-65. https://doi.org/10.1016/j.jenvman.2018.05.022

[20] Zhang, G., Liu, X., Lu, S., et al. (2020) Occurrence of Typical Antibiotics in Nansi Lake's Inflowing Rivers and Antibiotic Source Contribution to Nansi Lake Based on Principal Component Analysis-Multiple Linear Regression Model. Chemosphere 242, Article ID: 125269. https://doi.org/10.1016/j.chemosphere.2019.125269

[21] Xiong, Y. and Li, Q.K. (1990) Soils of China. 2nd Edition, Science Press, Beijing.

[22] Liao, K., Xu, S. and Zhu, Q. (2015) Development of Ensemble Pedotransfer Functions for Cation Exchange Capacity of Soils of Qingdao in China. Soil Use and Management, 31, 483-490. https://doi.org/10.1111/sum.12207 
[23] Seybold, C.A., Grossman, R.B. and Reinsch, T.G. (2005) Predicting Cation Exchange Capacity for Soil Survey Using Linear Models. Soil Science Society of America Journal, 69, 856-863. https://doi.org/10.2136/sssaj2004.0026

[24] Oorts, K., Vanlauwe, B. and Merckx, R. (2003) Cation Exchange Capacities of Soil Organic Matter Fractions in a Ferric Lixisol with Different Organic Matter Inputs. Agriculture, Ecosystems \& Environment, 100, 161-171. https://doi.org/10.1016/S0167-8809(03)00190-7

[25] Meyer, W.L., Marsh, M. and Arp, P.A. (1994) Cation Exchange Capacities of Upland Soils in Eastern Canada. Canadian Journal of Soil Science, 74, 393-408. https://doi.org/10.4141/cjss94-053

[26] Zhao, J.H., Xu, B.Y., Zhao, J.J., et al. (2019) Distribution Characteristics of Soil Cation Exchange Capacity in Haxi Forest of Qilian Mountains, Gansu Province. Forest Science and Technology, No. 6, 41-43.

[27] Shekofteh, H., Ramazani, F. and Shirani, H. (2017) Optimal Feature Selection for Predicting Soil CEC: Comparing the Hybrid of Ant Colony Organization Algorithm and Adaptive Network-Based Fuzzy System with Multiple Linear Regression. Geoderma, 298, 27-34. https://doi.org/10.1016/j.geoderma.2017.03.010

[28] Zhang, Q., Fang, H.L., Huang, Y.Z., et al. (2005) Application of Soil CEC to Evaluation of Soil Quality in Shanghai. Soils, 37, 679-682.

[29] Li, Y., Hao, Z.K., Shi, Q., et al. (2020) Distribution Characteristics of Soil pH, Cation Exchange Capacity and Organic Matter in the Area of Western Heilongjiang Province. Protection Forest Science and Technology, No. 4, 20-22.

[30] Khodaverdiloo, H., Momtaz, H. and Liao, K.H. (2018) Performance of Soil Cation Exchange Capacity Pedotransfer Function as Affected by the Inputs and Database Size. Clean-Soil Air Water, 46, Article ID: 1700670. https://doi.org/10.1002/clen.201700670

[31] Seyedmohammadi, J. and Matinfar, H.R. (2018) Statistical and Geostatistical Techniques for Geospatial Modeling of Soil Cation Exchange Capacity. Communications in Soil Science and Plant Analysis, 49, 2301-2314. https://doi.org/10.1080/00103624.2018.1499765

[32] Manrique, L.A., Jones, C.A. and Dyke, P.T. (1991) Predicting Cation-Exchange Capacity from Soil Physical and Chemical Properties. Soil Science Society of America Journal, 55, 787-794. https://doi.org/10.2136/sssaj1991.03615995005500030026x

[33] Obalum, S.E., Watanabe, Y., Igwe, C.A., et al. (2013) Improving on the Prediction of Cation Exchange Capacity for Highly Weathered and Structurally Contrasting Tropical Soils from Their Fine-Earth Fractions. Communications in Soil Science and Plant Analysis, 44, 1831-1848. https://doi.org/10.1080/00103624.2013.790401

[34] Rahal, N.S. and Alhumairi, B.A.J. (2019) Modelling of Soil Cation Exchange Capacity for Some Soils of East Gharaf Lands from Mid-Mesopotamian Plain (Wasit Province/Iraq). International Journal of Environmental Science and Technology, 16, 3183-3192. https://doi.org/10.1007/s13762-018-1913-6

[35] Khaledian, Y., Brevik, E.C., Pereira, P., et al. (2017). Modeling Soil Cation Exchange Capacity in Multiple Countries. CATENA, 158, 194-200.

https://doi.org/10.1016/j.catena.2017.07.002

[36] Hu, G.C. and Zhang, M.K. (2002) Mineralogical Evidence for Strong Cementation of Soil Particles by Iron Oxides. Chinese Journal of Soil Science, 33, 25-27.

[37] Martín-García, J.M., Sánchez-Marañón, M., Calero, J., et al. (2016) Iron Oxides and Rare Earth Elements in the Clay Fractions of a Soil Chronosequence in Southern 
Spain. European Journal of Soil Science, 67, 749-762.

https://doi.org/10.1111/ejss.12377

[38] Silva, L.S., Júnior, J.M., Barrón, V., et al. (2020). Spatial Variability of Iron Oxides in Soils from Brazilian Sandstone and Basalt. CATENA, 185, Article ID: 104258. https://doi.org/10.1016/j.catena.2019.104258

[39] Soares, M.R. and Alleoni, L.R.F. (2008) Contribution of Soil Organic Carbon to the Ion Exchange Capacity of Tropical Soils. Journal of Sustainable Agriculture, 32, 439-462. https://doi.org/10.1080/10440040802257348

[40] Zhang, M.K. and Zhu, Z.X. (1993) Effect of Slits on Cation Exchange Capacity of Soils. Soils and Fertilizers, 4, 41-43. 